\title{
Development of an Inclusive Interhospital Resource Allocation to Mitigate States Hospital Capacity during
} COVID-19

\author{
Eman A Toraih ${ }^{1}$, Danielle Tatum², Mohammad H Hussein ${ }^{3}$, Juan Duchesne ${ }^{4}$
}

\begin{abstract}
The severe acute respiratory syndrome coronavirus (SARS-CoV-2), commonly known as COVID-19, has resulted in severe resource shortages in the areas that have become hot spots. A leading area of concern has been hospital bed and intensive care unit bed availability that would leave hospitals unable to treat the most severe cases and which would result in unnecessary additional loss of life. Here, we present a model based on prediction of cases by state to propose resource allocation to alleviate hospital bed shortages.
\end{abstract}

Keywords: COVID-19, Emergency, Outcomes.

\section{Resumen}

El coronavirus del síndrome respiratorio agudo severo (SARS-CoV-2), comúnmente conocido como COVID-19, ha provocado una grave escasez de recursos en las áreas que se han convertido en regiones de alta prevalencia (puntos calientes). Una de las principales áreas de preocupación ha sido la disponibilidad de camas de hospital y de unidades de cuidados intensivos que dejan los hospitales sin poder tratar los casos más graves y que daría lugar a pérdidas de vidas adicionales innecesarias. Aquí te presentamos un modelo basado en la predicción de casos por estado para proponer la asignación de recursos para aliviar la escasez de camas hospitalares.

Palabras clave: COVID-19, emergencia, outcome.

Panamerican Journal of Trauma, Critical Care \& Emergency Surgery (2020): 10.5005/jp-journals-10030-1281

\section{BACKGROUND}

As of April 13, 2020, the United States has surpassed all other countries in number of confirmed novel coronavirus disease 2019 (COVID-19) cases with over 500,000 total, more than 6 times the reported numbers in China. ${ }^{1}$ Several states have experienced larger, more severe outbreaks than others, with New York, New Jersey, and Louisiana being among the worst. New York and New Jersey have the highest case numbers per capita in the nation, and Louisiana has second highest number of deaths per capita in addition to the fastest growth rate of cases in the world. ${ }^{2,3}$ Regions such as these are at high risk for soon exceeding their capacity to care for the steadily increasing number of infected and critically ill patients. Conversely, other states such as Mississippi, Wyoming, and the Dakotas have fared better with significantly fewer cases in defined areas as opposed to widespread transmission. Thus, United States began lockdown orders across many states, including schools and business (Table 1).

A recently published (though not yet peer reviewed) article estimated the predicted health service utilization and deaths due to the novel coronavirus in the United States over the next 4 months. ${ }^{4}$ Based on these forecasted estimates and state-level data, ${ }^{5}$ we examined which states would likely exceed hospital capacity and which would not over the coming days and months (Fig. 1 and Table 2). Our main objective was to potentially develop solutions for states with the nearest peak capacity based on an inclusive healthcare model that includes interhospital resource transfers with the less burdened by the pandemic.
${ }^{1}$ Division of Endocrine and Oncologic Surgery, Department of Surgery, Tulane University, School of Medicine, New Orleans, Louisiana, USA; Genetics Unit, Department of Histology and Cell Biology, Faculty of Medicine, Suez Canal University, Ismailia, Egypt

${ }^{2}$ Trauma Specialist Program, Our Lady of the Lake Regional Medical Center, Baton Rouge, Louisiana, USA

${ }^{3}$ Division of Endocrine and Oncologic Surgery, Department of Surgery, Tulane University, School of Medicine, New Orleans, Louisiana, USA

${ }^{4}$ Trauma/Acute Care and Critical Care, Department of Surgery, Tulane School of Medicine, New Orleans, Louisiana, USA

Corresponding Author: Juan Duchesne, Trauma/Acute Care and Critical Care, Department of Surgery, Tulane School of Medicine, New Orleans, Louisiana, USA, Phone: +1 504-988-5111, e-mail: jduchesn@ tulane.edu

How to cite this article: Toraih EA, Tatum $\mathrm{D}$, Hussein $\mathrm{MH}$, et al. Development of an Inclusive Interhospital Resource Allocation to Mitigate States Hospital Capacity during COVID-19. Panam J Trauma Crit Care Emerg Surg 2020;9(2):147-154.

Source of support: Nil

Conflict of interest: None

\section{Statistical Model}

Data were obtained from The Institute for Health Metrics and Evaluation (IHME) COVID-19 projections developed by the global health research center at the University of Washington School of Medicine (http://www.healthdata.org/covid). The analytical

() The Author(s). 2020 Open Access This article is distributed under the terms of the Creative Commons Attribution 4.0 International License (https://creativecommons. org/licenses/by-nc/4.0/), which permits unrestricted use, distribution, and non-commercial reproduction in any medium, provided you give appropriate credit to the original author(s) and the source, provide a link to the Creative Commons license, and indicate if changes were made. The Creative Commons Public Domain Dedication waiver (http://creativecommons.org/publicdomain/zero/1.0/) applies to the data made available in this article, unless otherwise stated. 
Table 1: Lockdown measures of Unites States

\begin{tabular}{|c|c|c|c|}
\hline State & Stay at home order & Educational facilities closed & Nonessential services closed \\
\hline Alabama & Not implemented & 18-Mar & 18-Mar \\
\hline Alaska & 25-Mar & 26-Mar & 18-Mar \\
\hline Arizona & Not implemented & 16-Mar & 20-Mar \\
\hline Arkansas & Not implemented & 17-Mar & 19-Mar \\
\hline California & 19-Mar & 19-Mar & 19-Mar \\
\hline Colorado & Not implemented & 23-Mar & 17-Mar \\
\hline Connecticut & 23-Mar & 17-Mar & 16-Mar \\
\hline Delaware & 24-Mar & 16-Mar & 16-Mar \\
\hline District of Colombia & Not implemented & 16-Mar & 16-Mar \\
\hline Florida & Not implemented & 17-Mar & 20-Mar \\
\hline Georgia & Not implemented & 18-Apr & Not implemented \\
\hline Hawaii & 25-Mar & 19-Mar & 17-Mar \\
\hline Idaho & Not implemented & Not implemented & Not implemented \\
\hline Illinois & 21-Mar & 17-Mar & 21-Mar \\
\hline Indiana & 25-Mar & 19-Mar & 16-Mar \\
\hline lowa & Not implemented & Not implemented & 17-Mar \\
\hline Kansas & Not implemented & 17-Mar & Not implemented \\
\hline Kentucky & Not implemented & 12-Mar & 16-Mar \\
\hline Louisiana & 23-Mar & 16-Mar & 17-Mar \\
\hline Maine & Not implemented & 15-Mar & 18-Mar \\
\hline Maryland & Not implemented & 16-Mar & 23-Mar \\
\hline Massachusetts & Not implemented & 17-Mar & 24-Mar \\
\hline Michigan & 24-Mar & 16-Mar & 23-Mar \\
\hline Minnesota & 27-Mar & 18-Mar & Not implemented \\
\hline Mississippi & Not implemented & 19-Mar & Not implemented \\
\hline Missouri & Not implemented & 23-Mar & Not implemented \\
\hline Montana & 26-Mar & 15-Mar & 26-Mar \\
\hline Nebraska & Not implemented & Not implemented & Not implemented \\
\hline Nevada & Not implemented & 16-Mar & 20-Mar \\
\hline New hampshire & 27-Mar & 16-Mar & 27-Mar \\
\hline New Jersey & 21-Mar & 18-Mar & 21-Mar \\
\hline New Mexico & Not implemented & 13-Mar & 24-Mar \\
\hline New York & 22-Mar & 18-Mar & 20-Mar \\
\hline North carolina & 30-Mar & 14-Mar & 30-Mar \\
\hline North Dakota & Not implemented & 16-Mar & Not implemented \\
\hline Ohio & 23-Mar & 16-Mar & 23-Mar \\
\hline Oklahoma & Not implemented & 17-Mar & Not implemented \\
\hline Oregon & 23-Mar & 16-Mar & Not implemented \\
\hline Pennsylvania & 23-Mar & 17-Mar & 23-Mar \\
\hline Rhode Island & 28-Mar & 16-Mar & 28-Mar \\
\hline South Carolina & Not implemented & 16-Mar & Not implemented \\
\hline South Dakota & Not implemented & 16-Mar & Not implemented \\
\hline Tennessee & Not implemented & Not implemented & Not implemented \\
\hline Texas & Not implemented & 19-Mar & Not implemented \\
\hline Utah & Not implemented & 16-Mar & Not implemented \\
\hline Vermont & 24-Mar & 18-Mar & 25-Mar \\
\hline Virginia & Not implemented & 16-Mar & Not implemented \\
\hline Washington & 23-Mar & 13-Mar & 25-Mar \\
\hline West Virginia & 25-Mar & 14-Mar & 24-Mar \\
\hline Wisconsin & 25-Mar & 18-Mar & 25-Mar \\
\hline Wyoming & Not implemented & 19-Mar & Not implemented \\
\hline
\end{tabular}




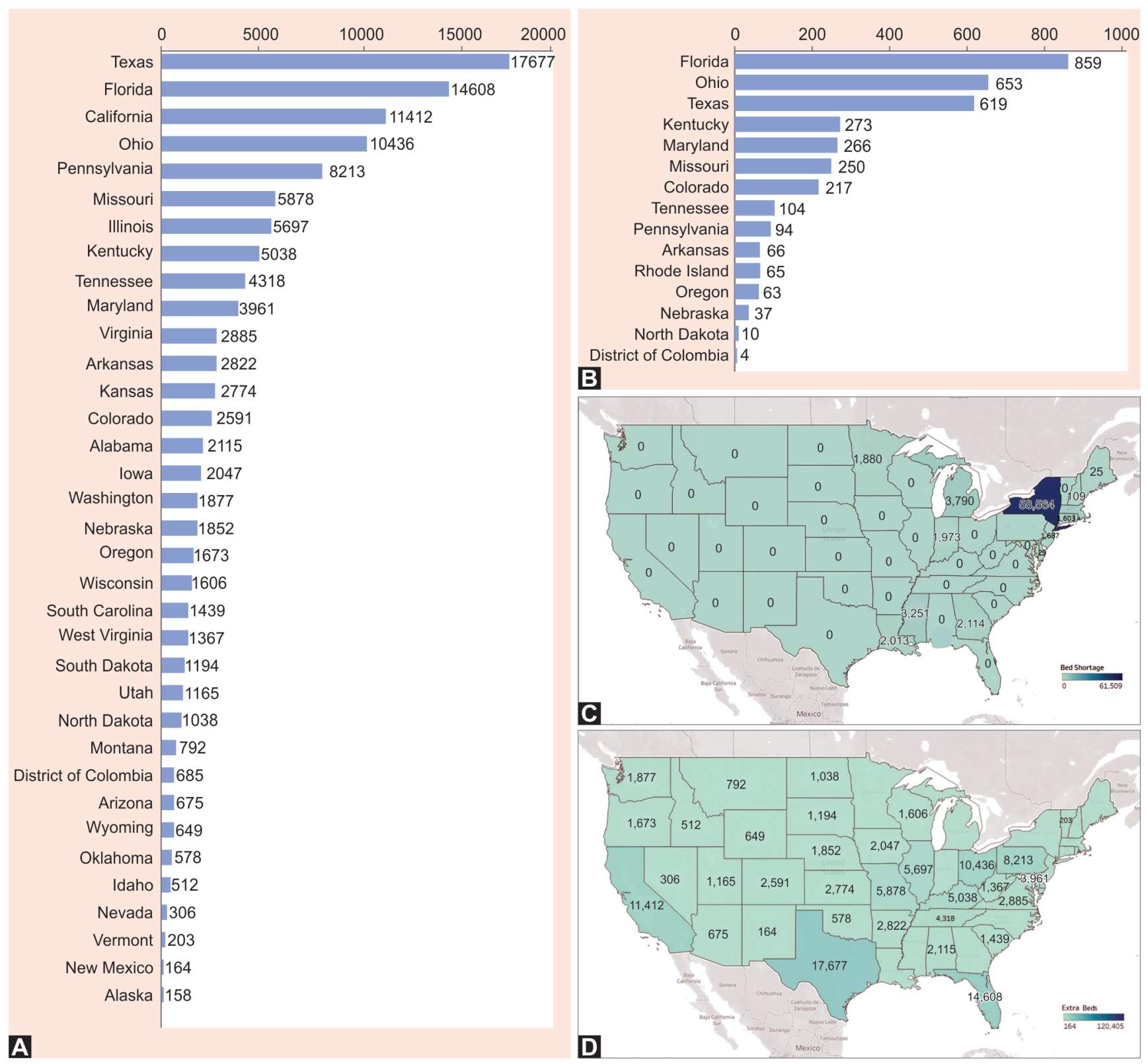

Figs 1 A to D: Density map illustrating areas of: (A) Estimated number and location of surplus hospital beds; (B) Estimated surplus and locations of ICU beds. Density map illustrating (C) Predicted number of additional hospital beds needed by state and (D) Predicted number of additional ICU beds needed by state

platform forecasts daily and cumulative COVID-19 deaths in association with social distancing order information and testing. For each state in the United States, the projected hospital and intensive care unit (ICU) bed needed were subtracted from the available resources to identify the presence of excess and shortage per State (Table 2).

\section{Supply and Demand}

As confirmed cases of COVID-19 in the United States continue to increase, the number of beds needed are exceeding what is locally available in many areas. For the whole of the country, an estimated 61,509 hospital beds and 15,103 ICU beds will be required within
14 days in order to meet demand. However, projected demand only significantly exceeds supply in certain states (Fig. 2). For example, New York state has 13,010 total hospital beds but is projected to need a staggering 71,574 , nearly 59,000 more than their current capability (Table 2). On March 30, 2020, New York received the US Naval hospital ship, the USNS Comfort, with 1,000 beds to alleviate pressure on overwhelmed hospitals. A similar ship, the USNS Mercy, was deployed to Los Angeles to expand critically needed hospital capacity there. However, the Navy alone cannot solve the bed shortage problem, particularly since much of the country is not accessible by port.

In contrast to these areas of crises, other areas are projected to have a surplus of thousands of beds, including those for ICU 


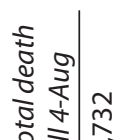

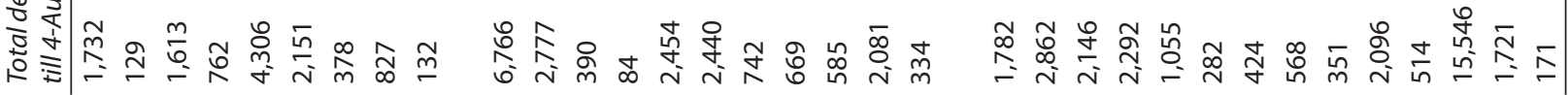

ฐิ

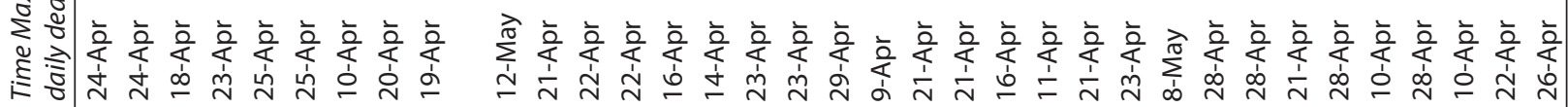

t

금ㅎㅎㅀ

:

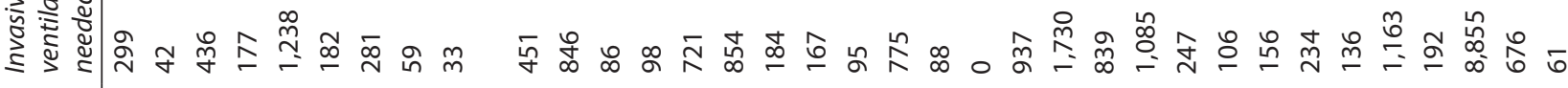

름

西

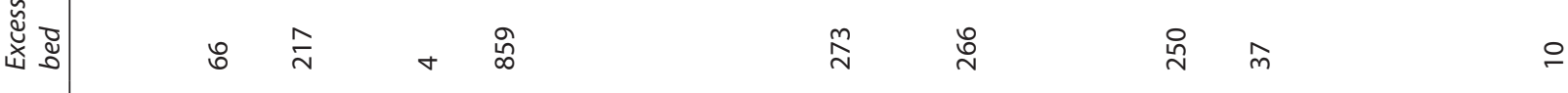

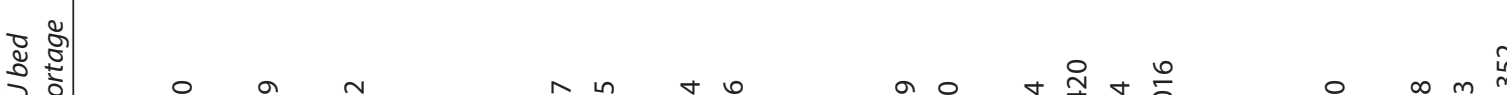

논

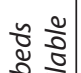

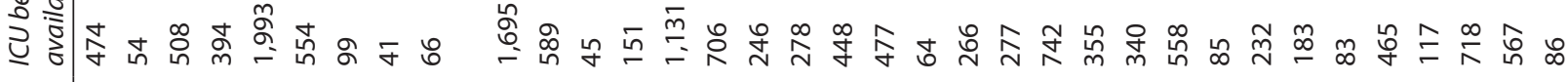

氖芯离

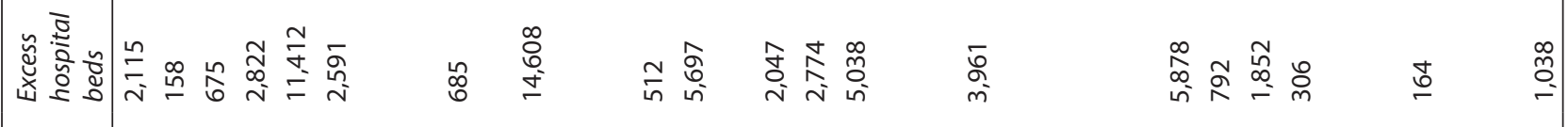

总

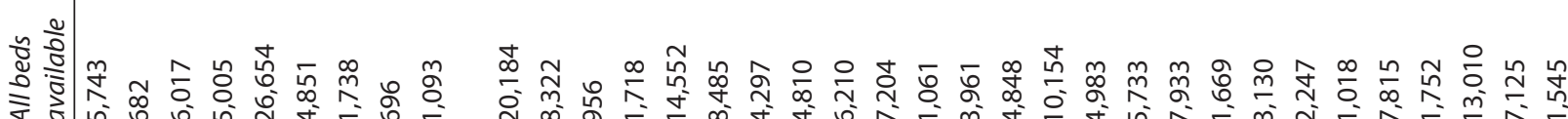

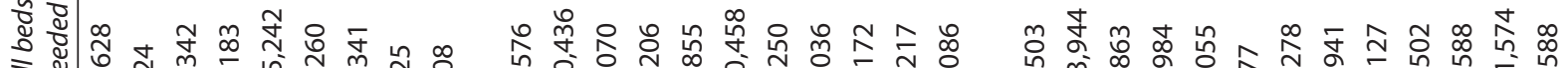

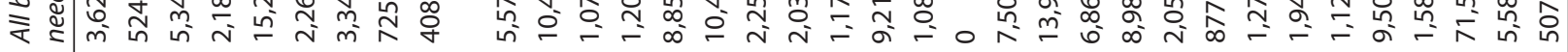
$\frac{d}{2} \frac{a}{a}$

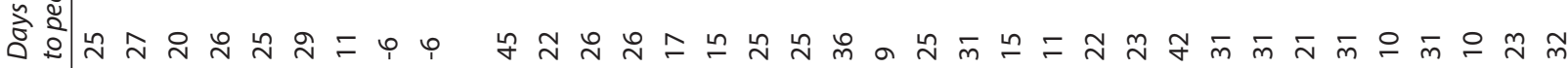
总

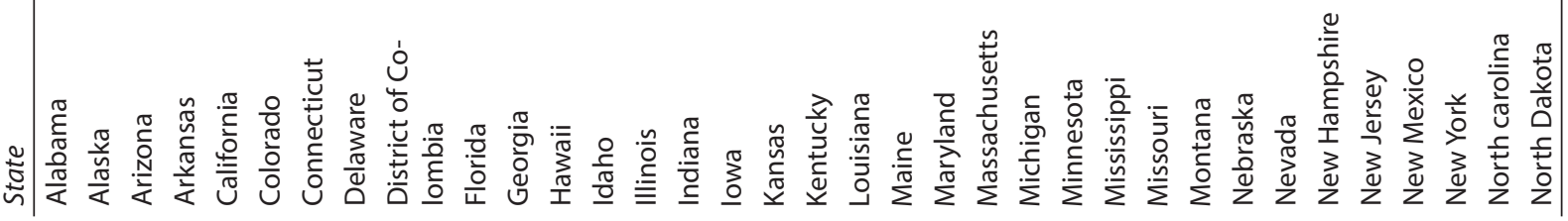




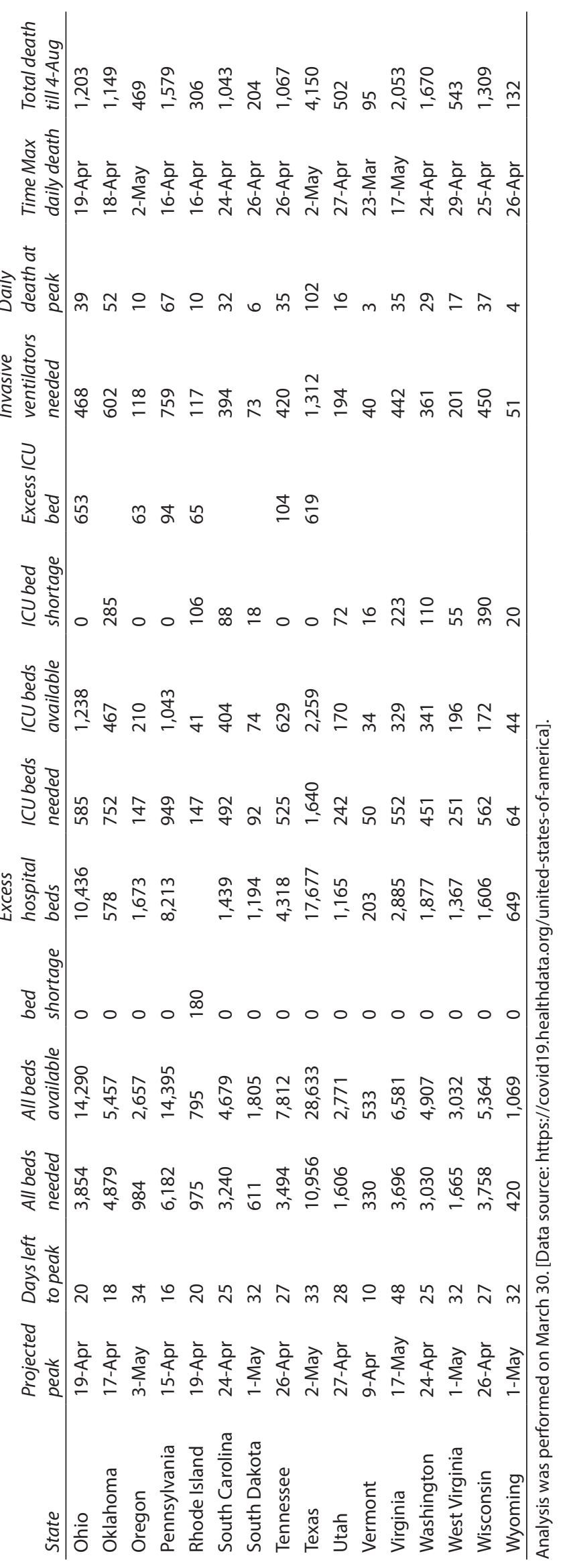



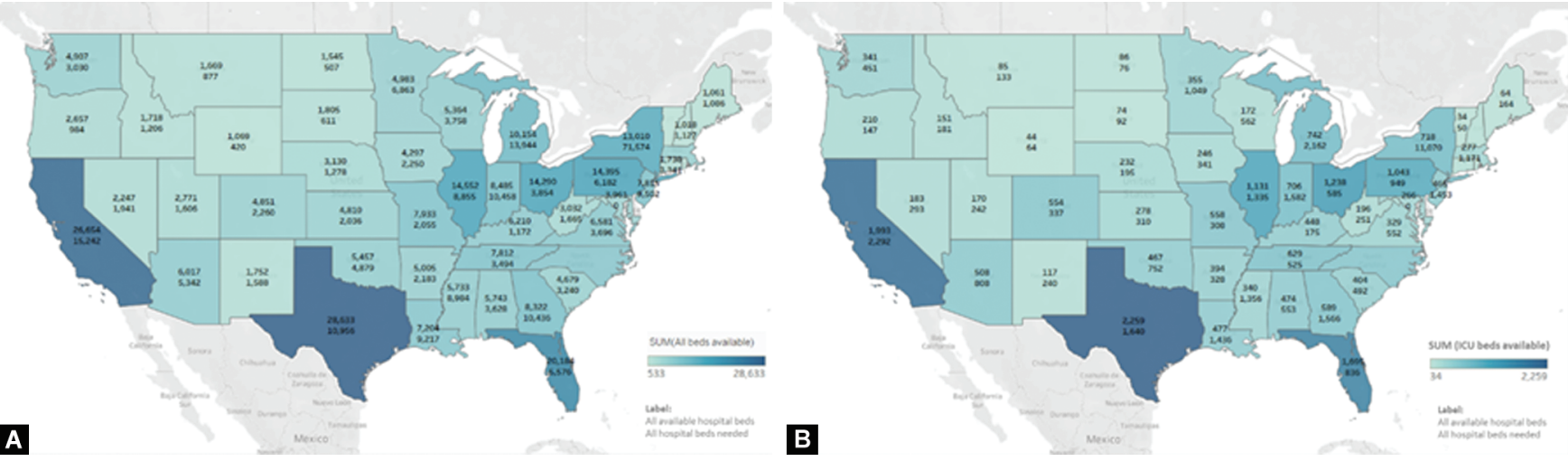

Figs 2A and B: Density map illustrating the total number of: (A) Estimated available hospital beds and predicted number needed; (B) Estimated available ICU beds and predicted number needed

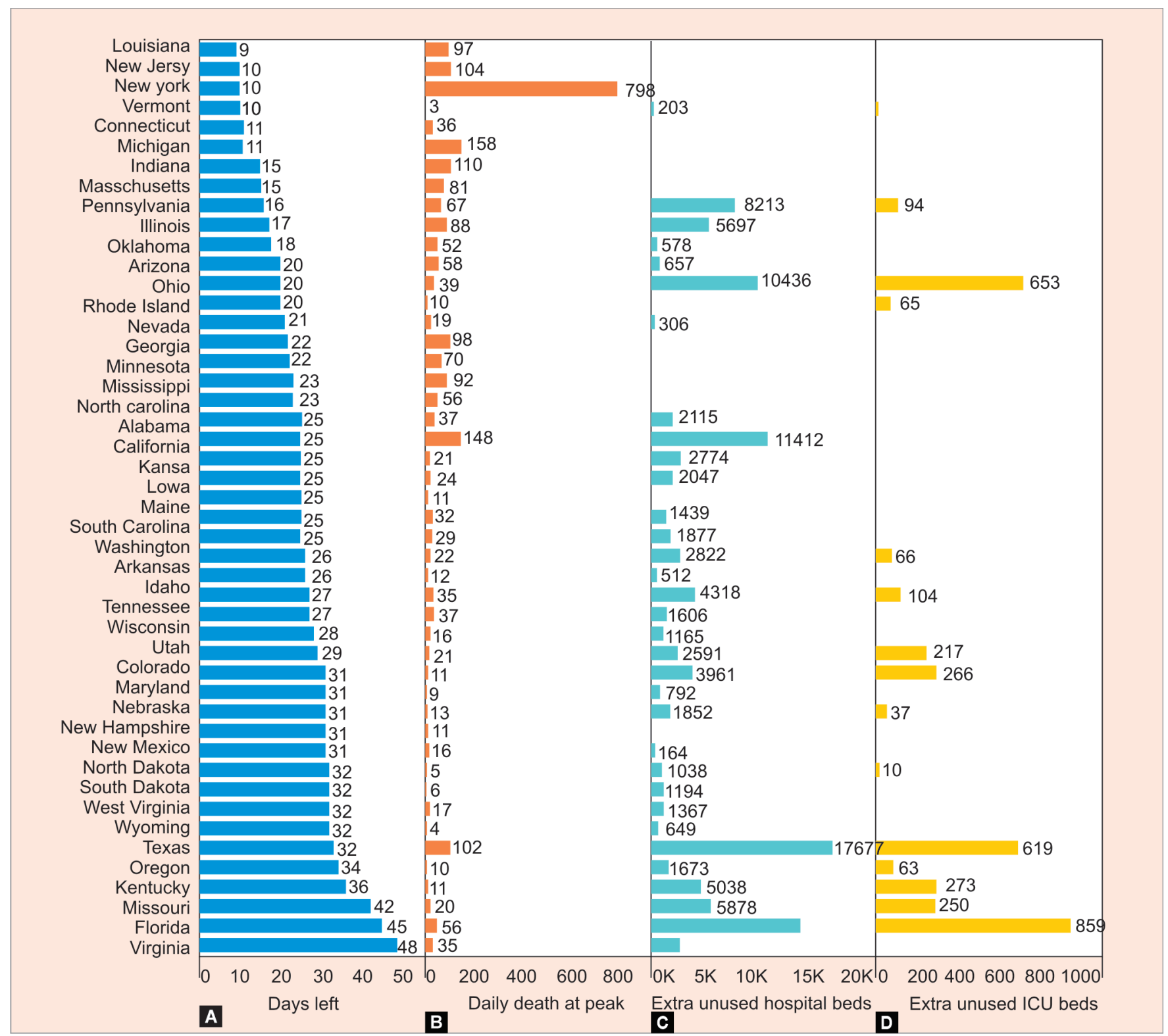

Figs 3A to D: (A) Timeline of days remaining until exceeding capacity; (B) Estimated number of daily deaths at peak of crisis; (C) A census of total hospital beds by the states; (D) A census of total ICU beds by the states 
care. As depicted in Figure 3, Pennsylvania is forecast to have nearly 8,000 available hospital beds, Ohio a surplus of more than 10,000 , and Texas nearly 18,000 unused beds throughout the next 4 months of this crisis. Ohio and Texas are also expected to each have approximately 600-650 available ICU beds, while several other states will potentially have between 100 and 260 that remain unused (Figs 3 C and D). Outbreaks are not uniform throughout the country, and different regions are beginning to see decreased numbers of new cases daily, while other regions are expected to not reach their peak for several more weeks or are developing fewer cases than originally predicted (Fig. 3A).

There current number of hospital beds in the United States is sufficient to meet demand; therefore, overall supply is not the problem. Rather, it is distinct areas of high demand which are rapidly approaching and exceeding hospital capacity (Fig. 2). Several places have begun to address this by repurposing existing structures such as dormitories and hotel rooms into makeshift hospital rooms. New Orleans, one of the hardest hit cities in the nation, has re-outfitted its large convention center, which was used to house victims of Hurricane Katrina as a stepdown facility for patients who do not require ICU care. While these structural transformations are helpful, they are also time intensive, costly, and alone may not be sufficient to meet demand.

\section{History Lessons}

During World War II, the nation witnessed massive scales of repurposing and reassigning resources. Car factories began making war planes seemingly overnight. Scores of women left the household for the first time to fulfill factories jobs left vacant by men going to war. Wartime required (what was then) radical thinking in order to adapt, and we again find ourselves in a war, albeit a different sort, and must engage in outside-the-box thinking. If America was a supermarket and facing supply shortages in some regions but surplus in others, the supply chains would be reconfigured and resources redistributed in order to meet demand in all stores. Indeed, we have already observed a sort of reallocation of resources in the form of medical personnel. Pleas from overburdened hospitals for additional medical personnel to treat COVID-19 patients have been made and are being answered in large numbers. In addition to the Navy hospital ship, approximately 80,000 healthcare providers have arrived in New York to volunteer and alleviate the strain on frontline staff.

Adding together the excess numbers from each state, there are projected to be roughly 120,405 available hospital beds and 3,580

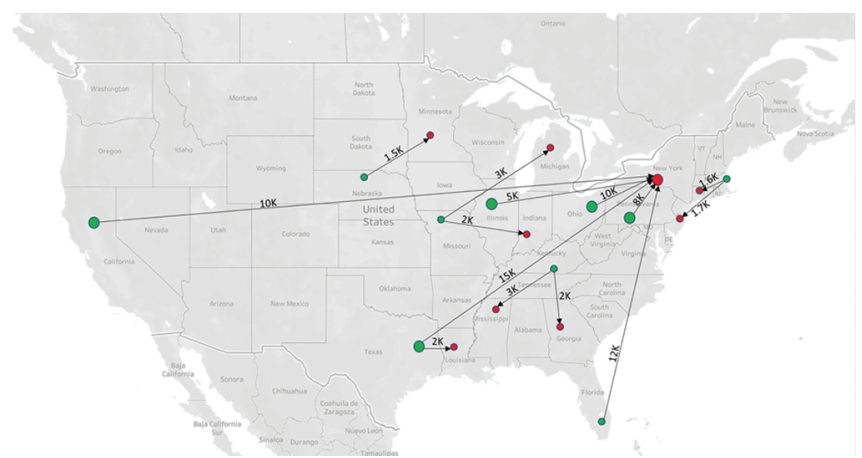

Fig. 4: Illustrated schematic of potential resource allocation maneuvers to alleviate resource shortages. Red circles represent areas of need, and green ones represent areas of surplus. $\mathrm{K}-1,000$
Table 3: Proposed national transfer of resources across states

\begin{tabular}{|c|c|c|c|c|}
\hline \multicolumn{2}{|c|}{$\begin{array}{l}\text { Allocation flow of hospital } \\
\text { beds }\end{array}$} & \multirow{2}{*}{$\begin{array}{l}\text { Excess } \\
\text { hospital } \\
\text { beds }\end{array}$} & \multirow[b]{2}{*}{ Needed beds } & \multirow{2}{*}{$\begin{array}{l}\text { Still spare } \\
\text { at the source }\end{array}$} \\
\hline From & To & & & \\
\hline Texas & LA & 17,677 & 2,000 & 15,677 \\
\hline Texas & NY & 15,677 & 15,000 & 677 \\
\hline Florida & NY & 14,608 & 12,000 & 2,608 \\
\hline Ohio & NY & 10,436 & 10,000 & 436 \\
\hline California & NY & 11,412 & 8,000 & 3,412 \\
\hline Illinois & NY & 5,697 & 8,000 & 213 \\
\hline Pennsylvania & NY & 8,213 & 5,000 & 697 \\
\hline Missouri & Indiana & 5,878 & 2,000 & 3,878 \\
\hline Missouri & Michigan & 3,878 & 3,000 & 878 \\
\hline Nebraska & Minnesota & 1,852 & 1,500 & 352 \\
\hline Kentucky & Georgia & 5,038 & 2,000 & 3,038 \\
\hline Kentucky & Mississippi & 3,038 & 3,000 & 38 \\
\hline Maryland & Connecticut & 3,961 & 1,600 & 2,361 \\
\hline Maryland & New Jersey & 3,961 & 1,700 & 661 \\
\hline
\end{tabular}

available ICU beds nationwide. Estimated projections predict that 61,509 hospital beds and 15,103 ICU beds will be needed. While it is currently not feasible to redistribute patients to hospitals with capacity for various reasons, we can reallocate our resources in order to get them to patients (Fig. 4). Such an approach could significantly alleviate strain on cities and hospitals that are nearing their breaking points. Proposed reallocation of resources is demonstrated in Table 3.

\section{Time is of the ESSENCE}

There is little time to act if lives are to be saved. Several states are projected to exceed their capacity in a matter of just days. Based on projected state-level timelines of days to reach capacity and the points at which estimated daily deaths will peak, the number of unused hospital beds in less affected areas can be a tool for mobilizing resources to where they are most needed. The approach is also fluid, as regions that are currently inundated will reach a peak in cases and begin to decline, thus freeing up resources which could then be allocated to new or developing areas of need. Although specific numbers are not included in the present discussion, the same approach could be applied to address the critical shortage of ventilators in overwhelmed areas. The country has ample infrastructure via railways, cargo planes, and cross-country trucking to allow rapid mobilization and redispersion of equipment to any of our states and territories in need.

\section{LiMITATIONS}

There are limitations to the data upon which our proposal is based, which, by extension, are limitations of our output as well. Age was not considered when the original forecast models were created. This may miss important and unique features in populations of states such as Florida with a significant proportion of geriatric patients. It has been well demonstrated that older COVID-19 patients have worse outcomes, and thus the real number of beds needed may exceed the estimated values. Additionally, these values are based on artificial intelligence projections based on available state data of licensed capacity and average annual occupancy rates and may not be $100 \%$ accurate as with any model. 
Finally, the proposed approach does not fully solve the forecast shortage of ICU beds. However, it does represent a meaningful start to address the issue.

\section{Conclusion}

In conclusion, we present an argument for a resource sharing/ re-allocation approach in order to mitigate future, but preventable, deaths due to regional lack of resources. This proposed approach is not intended to be a directive to be undertaken immediately. We recognize that there may be hesitancy to loan equipment based on a fear of the unknown in terms of future, not yet diagnosed cases. We further recognize that this may not be a feasible endeavor for every facility with available beds and that what we suggest is a complicated solution to a complicated problem. However, it is urgent that, at a minimum, we do due diligence and rapidly begin to assess the feasibility of sharing resources. When combating a virus which shows no concerns for borders or boundaries, can we afford to place such restrictions on ourselves at the expense of thousands of lives?

\section{References}

1. Johns Hopkins University \& Medicine Coronavirus Resource Center. Coronavirus COVID-19 Global Cases by the Center for Systems Science and Engineering (CSSE). Coronavirus COVID-19 Global Cases 2020. Available from https://coronavirus.jhu.edu/map.html. (Accessed April 13, 2020).

2. Governor's Office of Homeland Security and Preparedness site. COVID-19 Louisiana Response: Louisiana Case Info. Available at https://gov.louisianagov/assets/docs/covid/govCV19Brief-2.pdf. (Accessed April 13, 2020).

3. Louisiana Department of Health Office of Public Health. Louisiana Coronavirus (COVID-9) Information. Availabe at Idh.la.gov/ Coronavirus. (Accessed April 13, 2020).

4. IHME COVID-19 health service utilization forecasting team. Forecasting COVID-19 impact on hospital beds-days, ICU-days, ventilator days, and deaths by US state in thenext 4 months. medRxiv 2020. DOI: $10.1101 / 2020.03 .27 .20043752$.

5. Institute for Health Metrics and Evaluation (IHME). COVID-19 Projections. Seattle, WA: IHME, University of Washington; 2020. Available from https://covid19.healthdata.org/projections. (Accessed March 30, 2020). 